\title{
INTERVENÇÃO ARQUEOLÓGICA EM PATRIMÓNIO EDIFICADO: DOIS CASOS DE APLICAÇÃO DOS MÉTODOS DA ARQUEOLOGIA DA ARQUITECTURA EM CONTEXTO URBANO
}

\section{ARCHAEOLOGICAL INTERVENTION IN THE BUILT HERITAGE: TWO CASES OF APPLICATION OF THE METHODS OF THE ARCHAEOLOGY OF ARCHITECTURE IN THE URBAN CONTEXT}

\author{
Raquel Santos' \\ Arqueóloga, neoepica@gmail.com \\ Paulo Rebelo" \\ Arqueólogo,neoepica@gmail.com \\ Nuno Netoll' \\ Arqueólogo,neoepica@gmail.com
}

\begin{abstract}
This article aims to present two examples of the archaeology of architecture application in the urban context, namely a set of buildings in the historic center of Lagos and a building in the city of Lisbon. The examples given were the target of archaeological interventions with different objectives due to the context of work to which they were subjected: the first, sentenced to total demolition for the construction of a new building, the second being subject of a renovation work, affecting the structural elements only at the level of the wall coverings. Beyond the interpretation of data obtained for each of the buildings, we intend to present the conditions that determined the methodology to be used in each case.
\end{abstract}

Keywords: Lagos, Lisbon, Buildings, Wall surveys

\section{Resumo}

O presente artigo pretende dar a conhecer dois exemplos de aplicação dos métodos da arqueologia da arquitectura em contexto urbano, nomeadamente um conjunto edificado do centro histórico de Lagos e um prédio de habitação na cidade de Lisboa. Os exemplos dados foram alvo de intervenções arqueológicas com objectivos diferentes devido ao contexto de obra a que estavam sujeitos: o primeiro, condenado a demolição total para construção de um novo edifício; o segundo sofrendo uma obra de recuperação, afectando os elementos estruturais apenas ao nível dos revestimentos. Para além da interpretação dos dados obtidos para cada um dos edifícios, pretende-se apresentar as condicionantes que determinaram a metodologia a empregar em cada caso.

Keywords: Lagos, Lisboa, Edificado, Sondagens Parietais.

\section{Introdução}

No actual panorama de intervenção arqueológica em edifícios históricos, a tarefa do arqueólogo torna-se cada vez mais complexa, à medida que se complexificam também as metodologias de trabalho empregues. A necessidade de registo de todas as nuances cronológicas e históricas do edifício que se vem fazendo sentir levou à criação da Arqueologia da Arquitectura, que tem vindo a ser aplicada em Portugal desde os anos 90 do século XX e em restantes países da Europa já desde a década de 70 .
Os seus objectivos passam pelo registo preciso de todos os materiais e técnicas de construção presentes no edifício, bem como construções, alterações e remodelações efectuadas na sua estrutura, de forma a conhecer a sua evolução ao longo do tempo. Aplicando o método arqueológico e estratigráfico ao estudo do património construído, a Arqueologia da Arquitectura permite-nos obter através do edifício o conhecimento da comunidade e cultura que o envolve, bem como dos processos que levaram à sua construção, remodelação, destruição ou abandono. 
Pretende-se neste artigo utilizar como exemplo duas intervenções arqueológicas de emergência em contexto urbano e em edifícios de habitação que utilizaram os métodos da Arqueologia da Arquitectura, analisando o edificado como contexto arqueológico. Procurou-se, para além da caracterização e interpretação de cada conjunto edificado, apresentar os diferentes aspectos (prazos, contextos, equipas, financiamento, etc.) que enquadram e condicionam as metodologias próprias da Arqueologia da Arquitectura em intervenções deste tipo, expondo estratégias que procuram minimizar a acção destas condicionantes.

O edifício sito no $\mathrm{n}^{0} 28$ da Rua dos Bacalhoeiros, em Lisboa (Bac28), e o conjunto edificado que ocupava o quarteirão compreendido pelas ruas do Jardim, General Alberto da Silveira, Júlio Dantas e Travessa da Coroa, em Lagos (RJ21) - Portugal, são desta forma exemplos da aplicabilidade da Arqueologia da Arquitectura em contexto de arqueologia de emergência. No caso, duas intervenções arqueológicas da responsabilidade de uma empresa privada de serviços de arqueologia (Neoépica Lda.), as quais, embora partilhando o contexto comum da arqueologia de emergência e da arqueologia urbana, apresentam características e objectivos bastantes distintos entre si.

A intervenção a que se atribuiu o acrónimo Bac28 foi solicitada no decurso de um processo de reabilitação total de um edifício de habitação e comércio inserido na Zona Especial de Protecção da Baixa Pombalina, ocupando o espaço onde a Muralha Fernandina de Lisboa (século XIV) se encontrará com a Cerca Moura (século X-XII), actualmente numa rua de habitação e comércio do centro de Lisboa, com grande movimento, mesmo junto à Praça do Comércio. Tendo em conta a localização do imóvel e o facto de estar prevista uma intervenção de reabilitação que iria incidir sobretudo na substituição de revestimentos das paredes, considerou-se necessária a realização de trabalhos de arqueologia da arquitectura de forma a recolher informação acerca da constituição do edifício. Assim, a análise desenvolvida passou pela abertura de sondagens parietais em diversos espaços e pela observação integral das paredes após picagem ${ }^{1}$ dos rebocos antigos. Não houve lugar a sondagens no solo uma vez que a intervenção de reabilitação não abrangia qualquer tipo de trabalho no subsolo, operando apenas ao nível da estrutura do edifício (Figura 1).

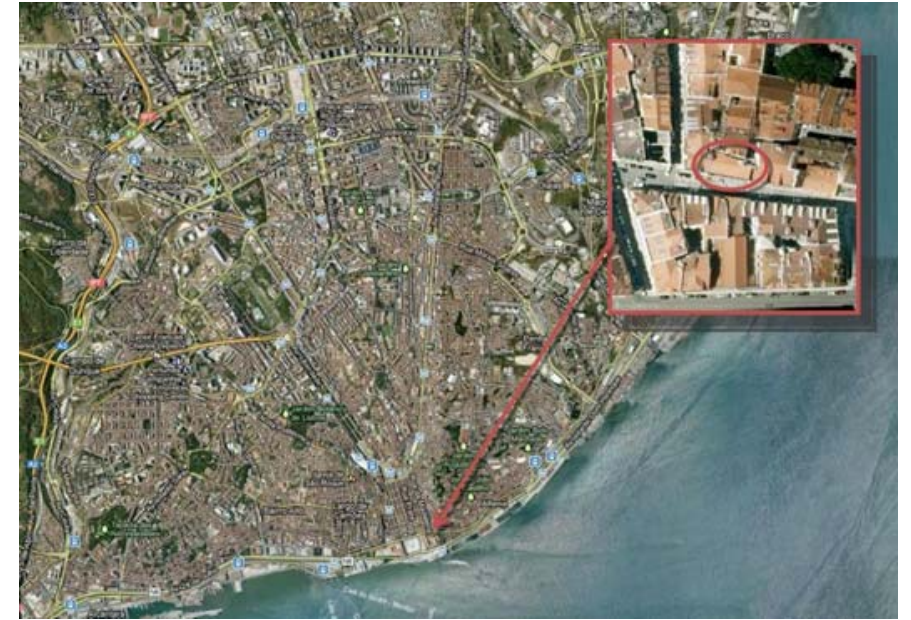

Figura 1. Localização do edifício da Rua dos Bacalhoeiros, $n^{0} 28$, na vista aérea de Lisboa (Fonte: www.maps.google.pt).

Já na RJ21, a intervenção arqueológica incidiu sobre o conjunto edificado que ocupava todo um quarteirão do centro histórico de Lagos, constituído por diversos edifícios já devolutos, entre eles uma casa senhorial e respectivo espaço ajardinado. $\mathrm{O}$ novo projecto a implementar previa a demolição na íntegra de todos os edifícios. Face a esta realidade, foi realizado não só o estudo parietal de todo o conjunto, através de sondagens parietais e picagens integrais de algumas paredes, mas também da ocupação do espaço ao longo dos tempos, recorrendo a sondagens no solo e escavação em área, após demolição das estruturas existentes (Figura 2).

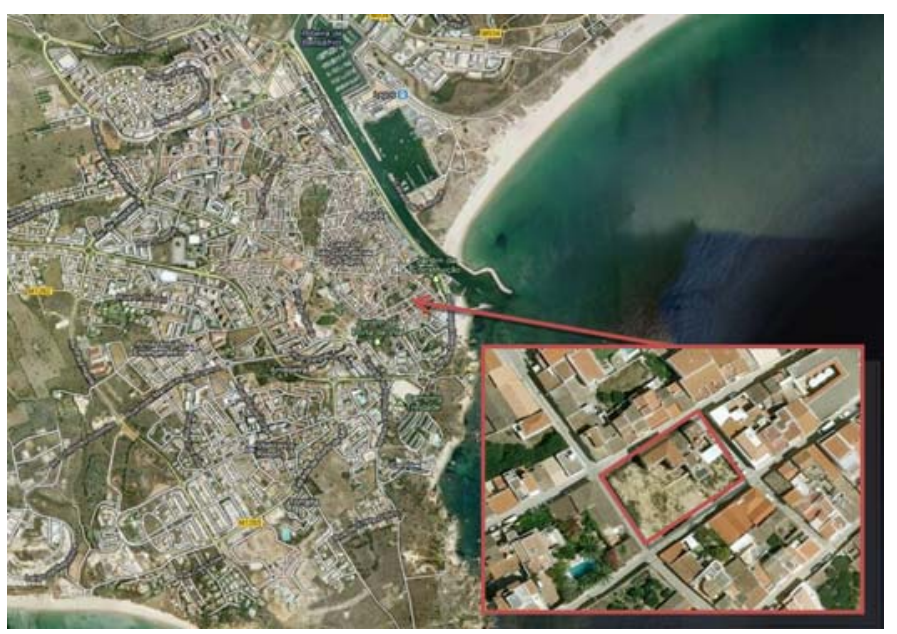

Figura 2. Localização do conjunto edificado da Rua do Jardim, n²1, na vista aérea de Lagos (Fonte: www.maps.google.pt).

\section{Rua dos Bacalhoeiros, 28}

A intervenção na Rua dos Bacalhoeiros, efectuada em 2007, decorreu de uma obra de remodelação total do prédio que, apesar de ter como condicionante a manutenção de todas as estruturas originais do edifício, incluiu a picagem integral dos rebocos e demais revestimentos existentes para efectuar a sua substituição. 
Estando o imóvel situado numa zona de grande sensibilidade arqueológica, quer por se encontrar na Zona Especial de Protecção da Baixa Pombalina, quer por ocupar o espaço onde, segundo o traçado das muralhas de Lisboa, se encontra a confluência da Muralha Fernandina e Cerca Moura, foram efectuadas primeiramente diversas sondagens parietais a fim de registar os métodos e tipos de aparelho utilizados na construção do edifício, bem como os seus diversos revestimentos e rebocos (antes de serem removidos no decurso da obra), sendo posteriormente feita a sua análise estrutural. Uma vez que os trabalhos de remodelação não previam qualquer tipo de movimentação de solo, não houve lugar à abertura de sondagens horizontais.

Assim, os objectivos da intervenção passavam pela identificação dos (1) métodos construtivos utilizados; (2) tipos de aparelho; (3) sucessão de rebocos e revestimentos; (4) alterações efectuadas à estrutura do edifício e (5) possíveis vestígios de Muralha Fernandina ou Cerca Moura ao nível dos pisos superiores, ocupados por apartamentos. Pretendia-se ainda acompanhar a execução da substituição de rebocos e revestimentos, salvaguardando a estrutura original do edifício.

\section{Trabalhos realizados}

Para atingir os objectivos propostos, foram realizadas sondagens parietais que seguiram a metodologia arqueológica empregue nas sondagens horizontais: decapagem de todo o revestimento da parede por camadas estratigráficas, fazendo-se o seu registo escrito (descrição da realidade identificada) e fotográfico.

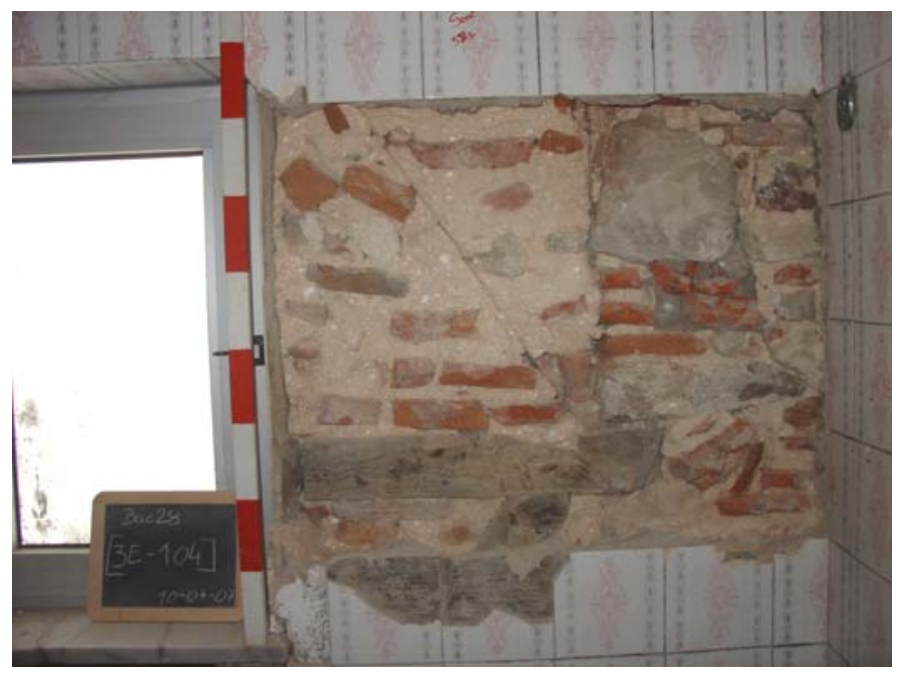

Figura 3. Sondagem parietal efectuada no $2^{\circ}$ Andar.

Estas sondagens implantaram-se em todos os andares (à excepção da cave, ocupada por espaços comerciais, que estavam fora do âmbito da remodelação) e na maioria dos compartimentos do edifício (constituído por cave, rés do chão e dois andares, existindo em cada andar dois apartamentos, cada um deles com diversos compartimentos/salas), num total de 14 sondagens, de dimensões variáveis (Figura 3).

Infelizmente, todas as sondagens parietais se situavam no interior do prédio, uma vez que à data de início dos trabalhos arqueológicos, o exterior se encontrava já finalizado, com novo revestimento. Para cada sondagem efectuada foram preenchidas fichas descritivas, onde consta a descrição do aparelho construtivo, bem como de todas as camadas de revestimento, atribuindo-se a cada uma delas um número de unidade estratigráfica (Figura 4).

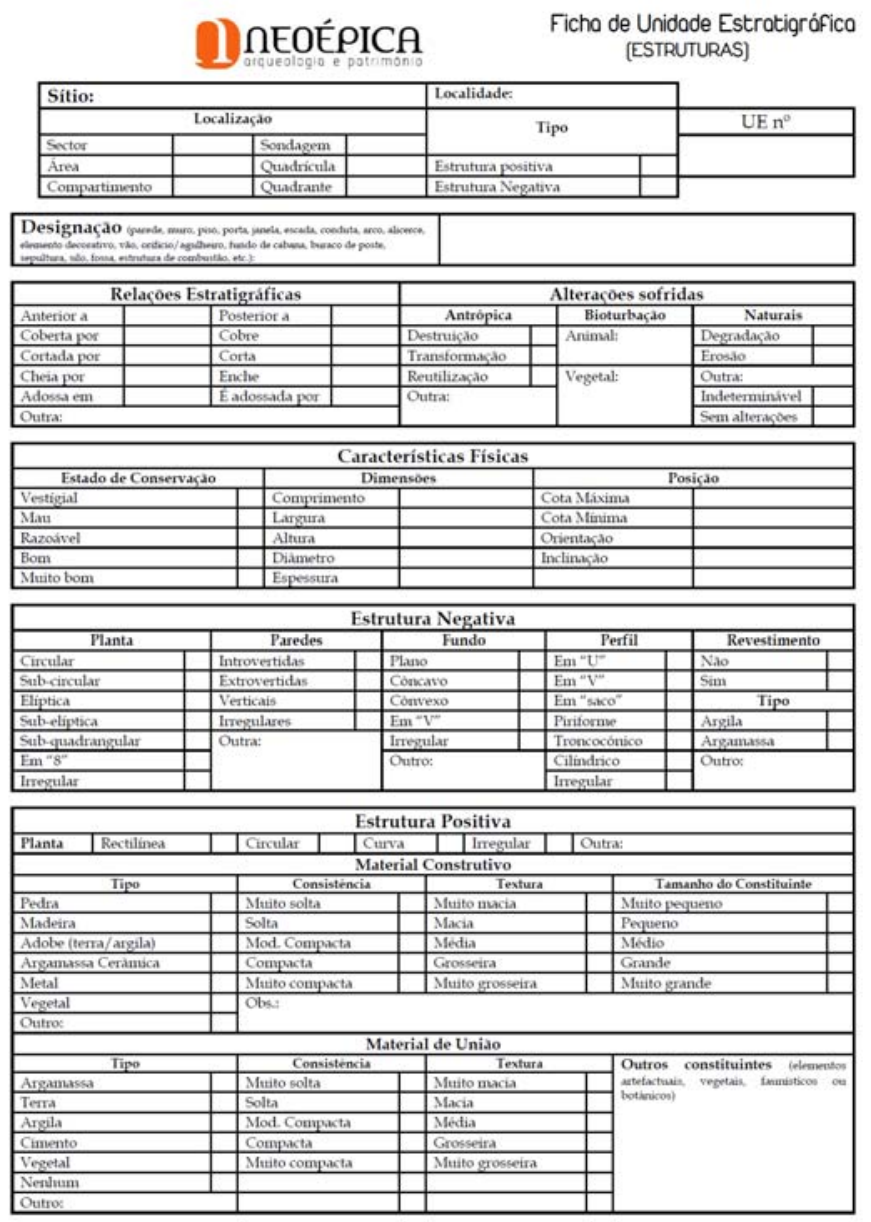

Figura 4. Ficha descritiva de Unidades Estratigráficas.

Posteriormente à picagem integral das paredes, efectuouse uma memória descritiva ou descrição estrutural do prédio com base na observação das estruturas, bem como o seu levantamento fotográfico exaustivo.

Tanto as sondagens como a análise estrutural efectuada revelaram apenas três tipos de aparelho utilizado no projecto inicial do edifício: (1) em pedra e tijolo para as paredes-mestras; (1) em pedra e tijolo com estrutura de "gaiola" para as paredes centrais, que formam a escada; e (3) em tabique, com tábuas e pequenas ripas de madeira, para as paredes divisórias dos apartamentos. 
Mais especificamente, observamos ao nível do piso mais elevado que toda a estrutura do telhado é suportada por grandes vigas de madeira, sendo o soalho do sótão suportado por barrotes. O facto de existir um reboco cuidado nas paredes do sótão e dois armários que escondem escadas de acesso nos apartamentos do $2^{\circ}$ andar, indica que este espaço seria originalmente utilizado, muito embora tenha apenas $1,5 \mathrm{~m}$ de altura na junção das duas águas.

Por outro lado, o facto de existirem duas traves mestras paralelas que partem da junção das águas do telhado em direcção à fachada, terminando ao nível do piso deste andar, numa estrutura de beirado ainda perfeitamente conservada, poderá indicar que, originalmente, este segundo piso seria de águas furtadas - mais baixo, ocupando ele próprio o espaço de sótão. Em determinada altura, as paredes-mestras terão sido acrescentadas a partir do nível daquelas traves, construindo-se novo telhado com beirado idêntico ao primeiro, mantendo-se este. Talvez por isso se note uma ligeira alteração ao aparelho das paredes que utilizam a "gaiola": é que a este nível, verifica-se uma predominância do tijolo, cuidadosamente posicionada (embora entre espessas camadas de argamassa), havendo mesmo paredes onde não parece ter sido utilizada qualquer pedra.

As paredes Norte, Oeste e Sul (paredes mestras) do edifício apresentam um aparelho de alvenaria de pedra calcária, de pequenas e médias dimensões e formato irregular, que inclui fragmentos de tijolo em grande quantidade, unido por argamassa de tom alaranjado e consistência compacta, com areão grosseiro e pequenos fragmentos malacológicos. A parede divisória que comunica com a área da escada é em "gaiola": estruturada por grandes vigas de madeira com travamento das diagonais em cruz, apresenta idêntica quantidade de argamassa de tom alaranjado e consistência compacta e de tijolo (inteiro ou pouco fragmentado), bem como alguma pedra calcária de pequenas dimensões em pouca quantidade. $\mathrm{O}$ tijolo encontra-se disposto não aleatoriamente, mas em várias direcções. Os restantes compartimentos são totalmente elaborados em tabique (taipa de fasquio): composto por grandes tábuas dispostas verticalmente e unidas por pequenas ripas de madeira horizontais, fixadas a elas através de taxas de ferro (Figura 5).
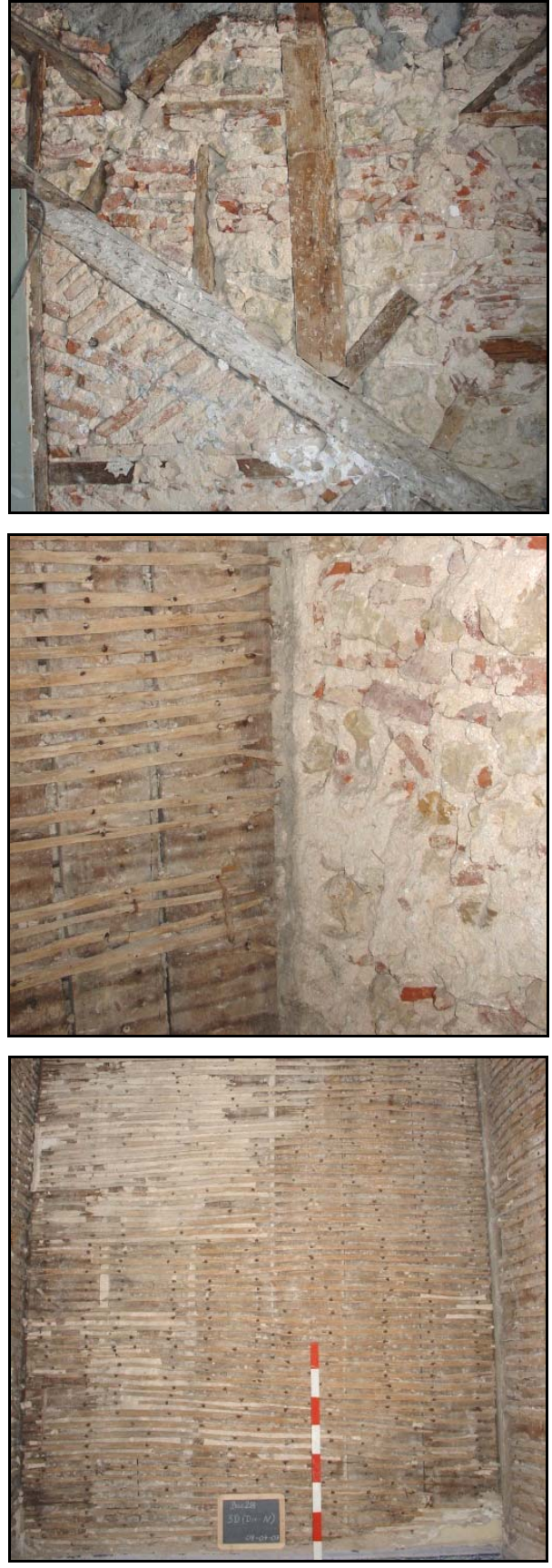

Figura 5. Pormenores das diferentes técnicas construtivas utilizadas.

As chaminés existentes são totalmente constituídas por tijolo e argamassa de tom alaranjado e consistência compacta, revestida por uma argamassa de tom mais rosado. Para estruturar a parte de cima da chaminé são utilizadas vigas de madeira (Figura 6). 


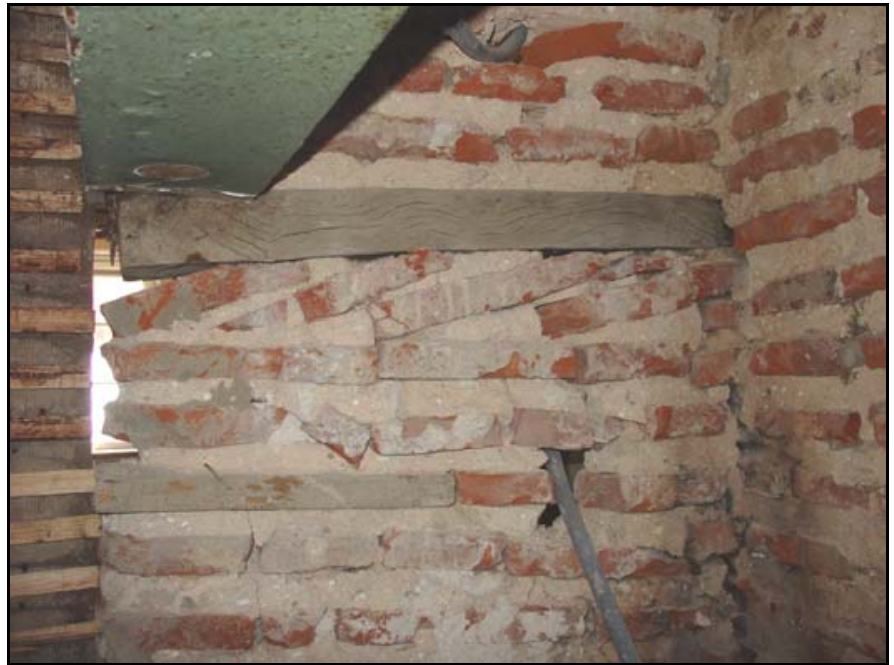

Figura 6. Pormenor da chaminé.

As portas e janelas, bem como os seus vãos, são emolduradas por grandes barrotes de madeira, sendo a estrutura exterior das janelas viradas a Sul (Rua dos Bacalhoeiros) em pedra calcária. As janelas viradas a Norte (Beco) são encimadas por tijolo disposto verticalmente, em arco abatido, com parapeito constituído por uma laje de pedra calcária. O chão é inteiramente constituído por soalho: tabuado de madeira assente em barrotes transversais.

Nos apartamentos $2^{\circ}$ Dto e $1^{\circ}$ Esq observam-se faixas ou painéis de azulejos que decoram as paredes dos compartimentos, excepção feita ao espaço da cozinha e hall de entrada. De uma maneira geral, é possível dizer que os painéis de azulejo observados nestes apartamentos têm características semelhantes ao azulejo pombalino (policromia, repetição de motivo enquadrada por uma cercadura de motivo diferente, monocromática - 176080), muito difundido nessa época pelo seu baixo custo e elevada resistência. Por outro lado, eles constituíam igualmente uma forma simples e económica de decoração e, consoante o tipo, poderiam conferir maior ou menor opulência aos espaços que revestiam.

Ao nível do segundo andar, encontramos painéis policromos (pintados a amarelo, verde e manganês), com motivos fitomórficos, enquadrados por cercaduras monocromáticas (pintadas a azul), com motivos geométricos, diferentes em cada sala. O conjunto tem uma altura de quatro azulejos, com excepção para uma das salas onde o painel é constituído apenas pela cercadura (parte superior e inferior), tendo assim uma altura de 2 azulejos.

Ao nível do primeiro andar, verifica-se a existência de painéis mais elaborados, embora monocromáticos (pintados a azul), com 7 azulejos de altura, compostos por: painel central em estilo albarrada, com motivo de ramos de flores em jarras, em conjuntos de $4 \times 1$ ou $4 \times 3$ peças, alternadamente; cercadura com motivo geométrico; e uma segunda cercadura inferior em azulejo esponjado, pintado a cor-de-rosa por intermédio de uma esponja (Figura 7).

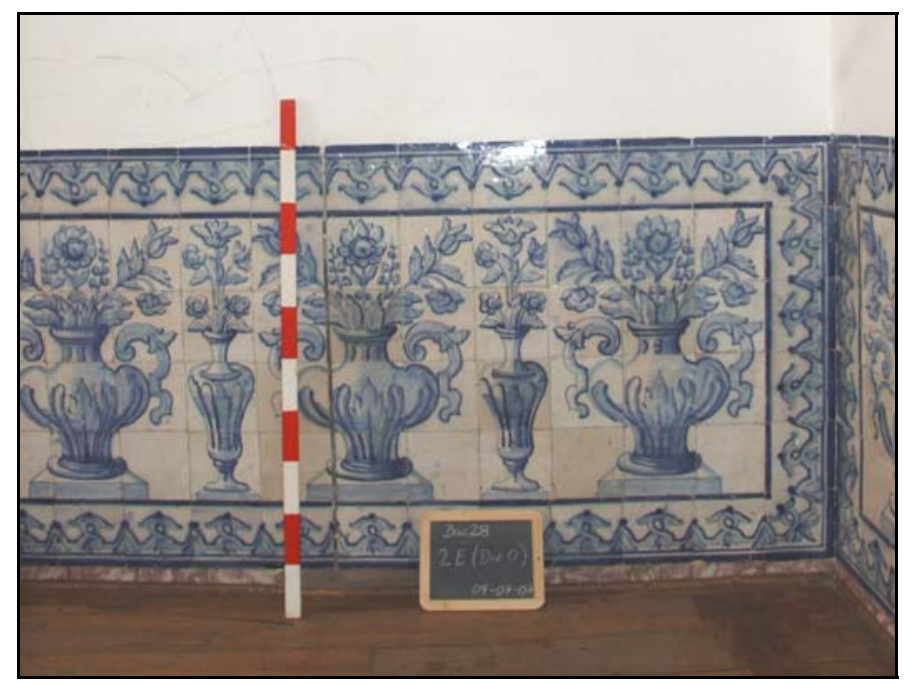

Figura 7. Painel de azulejo do $1^{\circ}$ andar.

A escada de acesso aos vários apartamentos do prédio é inteiramente constituída por madeira, sendo a parede central em tabique e as paredes laterais, que comunicam com os apartamentos, em "gaiola” (Figura 8).

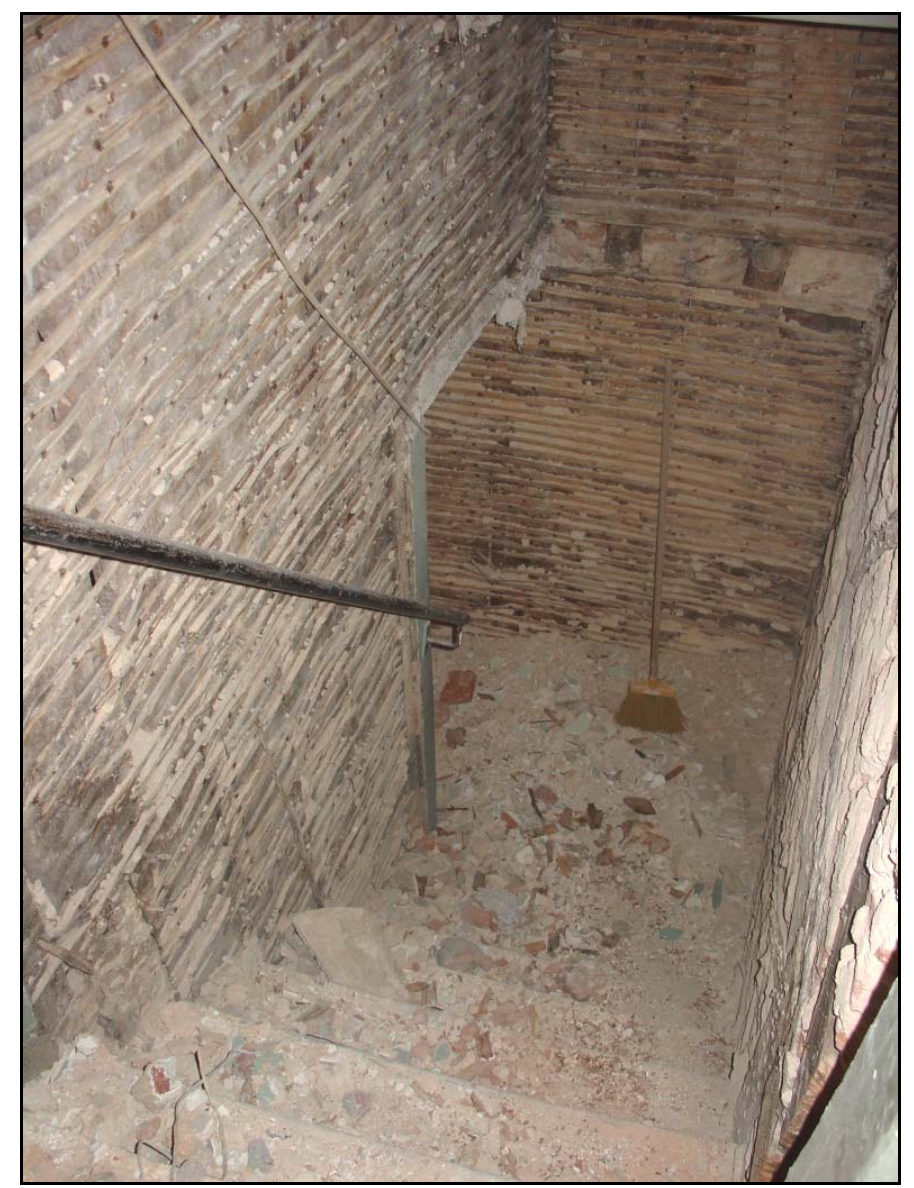

Figura 8. Técnica construtiva utilizada na escada. 
O hall de entrada do prédio foi em parte ocupado pelos proprietários do R/C Dto. que aí construíram o seu próprio hall, aumentando assim uma divisão à casa. Não obstante, mesmo esta estrutura foi construída em madeira, com tabuado vertical e pequenas ripas horizontais e barrotes que formam as esquinas e sustentam o tecto, também em tábuas.

A porta de entrada do edifício, com soleira constituída por laje de pedra calcária, é encimada por uma estrutura de tijolo, disposto verticalmente em arco abatido, e abre para o primeiro lanço da escada, com quatro degraus. $\mathrm{O}$ piso do hall de entrada é revestido por mosaico de $25 \mathrm{x}$ $25 \mathrm{~cm}$, bem como o primeiro patamar. Todos os outros são em tabuado de madeira, semelhante aos próprios degraus. Os restantes lanços da escada têm sucessivamente quatro, sete, seis e nove degraus.

A parede central da escada, em tabique, é de constituição idêntica às paredes divisórias dos apartamentos: grandes tábuas dispostas verticalmente e unidas por pequenas ripas de madeira horizontais, fixadas a elas através de taxas de ferro. As esquinas são formadas por barrotes e vigas de madeira. A parede Sul é do mesmo tipo, a parede Norte de alvenaria de pedra e tijolo e as parede Este e Oeste são estruturadas por "gaiola”. A maioria dos vãos deixados pelos lanços de degraus é aproveitada como despensa dos apartamentos.

\section{Síntese interpretativa}

De uma maneira geral, mesmo não tendo sido possível em nenhum momento observar na íntegra a constituição de cada uma das paredes, verifica-se que o prédio segue um método de construção simples, utilizando preferencialmente a madeira como material. As paredesmestras, quer das fachadas quer as que comunicam com os edifícios de ambos os lados, são constituídas por alvenaria de pedra calcária, de pequenas e médias dimensões e formato irregular, que inclui fragmentos de tijolo em grande quantidade, unida por argamassa de tom alaranjado e consistência compacta, revestida no interior por uma argamassa de tom mais rosado, por sua vez revestida por reboco fino de argamassa de tom branco e, em alguns casos, por estuque com pintura simples.

Nas paredes centrais, aquelas que fazem a comunicação dos apartamentos com a escada, foi utilizada a estrutura de "gaiola", em vigas de madeira com travamento em cruz de Santo André, preenchidas depois por um aparelho maioritariamente de tijolo e argamassa compacta de tom alaranjado. Também estas seriam revestidas por argamassa de tom rosado e reboco fino (Figura 9).

Já as paredes que formam as divisões dentro dos apartamentos, bem como as paredes meeiras da escada, são constituídas por tabique, composto por grandes tábuas de madeira dispostas verticalmente e unidas por pequenas ripas de madeira horizontais em ambos os lados, fixadas a elas através de taxas de metal. Este tipo de parede seria revestido por uma camada espessa de argamassa e esta por um reboco fino (Figura 10).

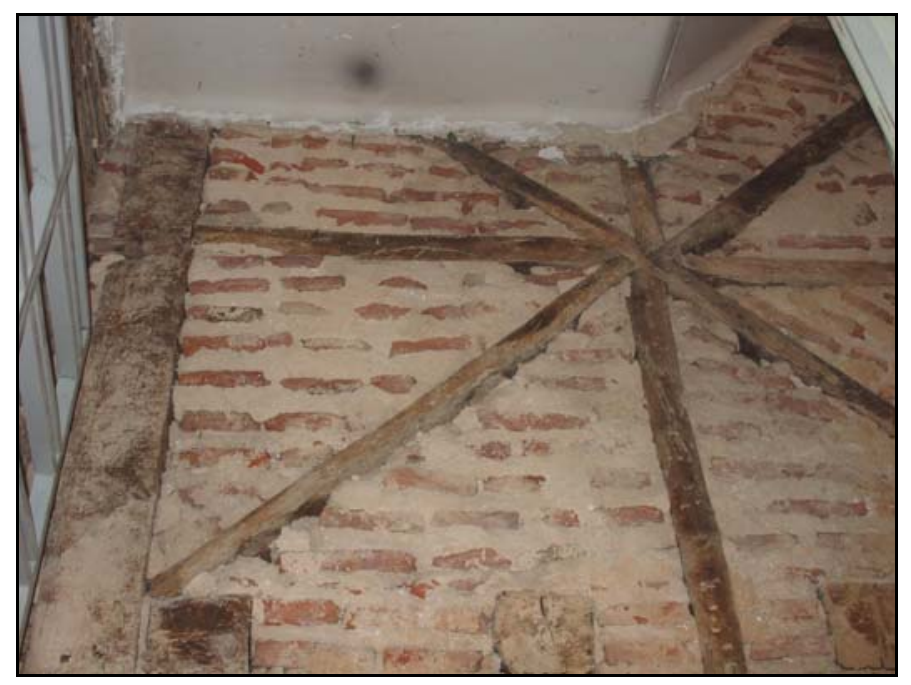

Figura 9. Parede de "gaiola".

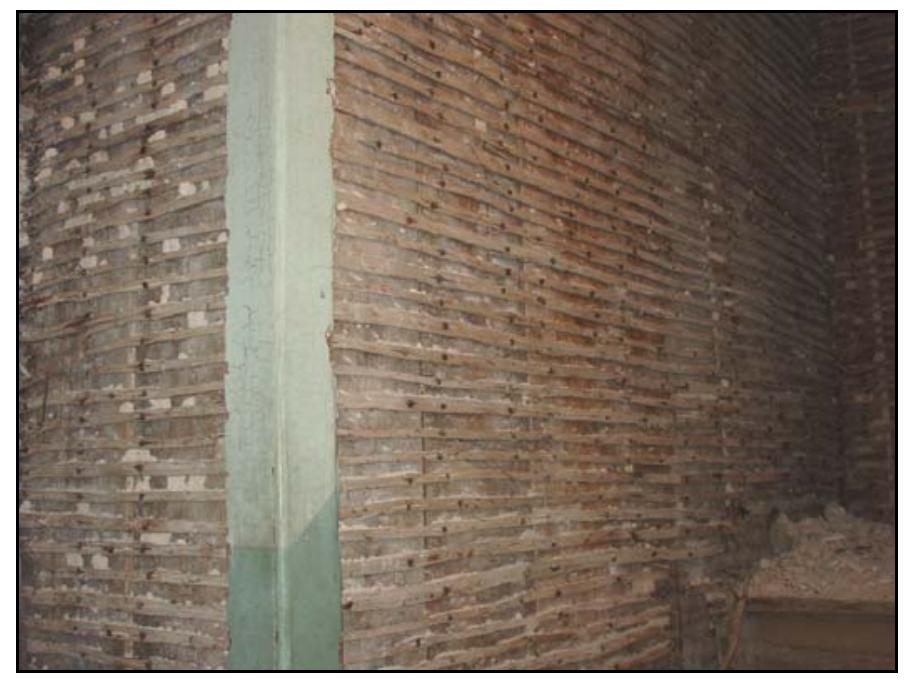

Figura 10. Parede divisória em tabique.

Em termos de composição dos apartamentos e organização de espaços interiores nota-se, desde logo, a grande quantidade de portas (comparativamente às casas actuais), fazendo a ligação de todas as salas entre si e suprimindo assim a necessidade de um corredor. Desta forma, excepção feita para as paredes-mestras que comunicam com os edifícios vizinhos de ambos os lados e para a parede de comunicação com a escada, todas as paredes (mestras ou interiores) possuem pelo menos uma abertura, quer seja em forma de janela ou porta. As funções de cada compartimento são ainda nesta época pouco diferenciadas, havendo no entanto uma chaminé em cada casa. As casas de banho terão sido construídas posteriormente, aproveitando na maioria dos casos parte do espaço da cozinha. A inexistência de casa de banho 
levava a que muitos dos prédios da Lisboa antiga possuíssem um sistema de despejos que era feito através de uma espécie de "conduta” construída numa das paredes, o que não parece ser o caso deste edifício, considerando-se por conseguinte que os despejos seriam feitos manualmente, quiçá ainda seguindo o velho costume da "água vai”...

Uma outra particularidade deste edifício, é a existência de uma porta de comunicação entre os apartamentos do lado direito e do lado esquerdo, que se deve ao costume de alugar a divisão situada ao meio quer a um quer a outro consoante a necessidade, ou até mesmo independentemente, nos casos em que esta tem comunicação directa para a escada (não é o caso neste edifício).

A título de curiosidade, ainda um apontamento para o sistema de abertura da porta de entrada no prédio, totalmente manual, que consistia num cabo, ligado ao trinco, que percorria toda a altura do prédio. Em cada andar, à entrada dos apartamentos, existia um manípulo junto ao chão que, quando levantado, fazia abrir a porta. Um sistema manual semelhante, embora em menor escala, abria as janelas do $\mathrm{R} / \mathrm{C}$, apartamento este que por ter o piso a uma cota mais baixa que a do beco a Norte, necessitava de janelas junto ao tecto nesta fachada.

Muito embora não tenha sido possível identificar, nas áreas observadas, vestígios da Muralha Fernandina ou da Cerca Moura, a análise realizada permitiu um conhecimento bastante alargado dos métodos e materiais de construção empregues neste edifício, bem como dos espaços domésticos que permitem até tecer algumas considerações acerca da vida privada dos seus habitantes.

O tipo de aparelho utilizado, embora possa remontar a uma época de construção (ou reconstrução) no pósterramoto, aquando da implementação do plano pombalino na baixa da cidade, é concordante com o primeiro registo conhecido do prédio de 1840 . Não se verificaram alterações significativas ao projecto inicial. Para além das necessárias remodelações ao nível de rebocos e pintura, surgem apenas algumas alterações no que concerne aos vãos de janela (encurtados com paredes de cimento e tijolo) e a algumas paredes divisórias (que aparentam ter sido construídas recentemente). Verificouse ainda a influência de algumas modificações sociais, que se traduziram em emparedamentos de algumas portas, construção de casas de banho aproveitando parte das cozinhas e instalações de água e electricidade que não existiriam (SANTOS, 2007).

\section{Rua do Jardim, 21}

O quarteirão limitado pelas ruas do Jardim, General Alberto da Silveira, Júlio Dantas e Travessa da Coroa, no centro histórico da cidade de Lagos (Algarve - Portugal), foi integralmente estudado do ponto de vista arqueológico através da intervenção arqueológica que se iniciou em Novembro de 2005 (Figura 11).

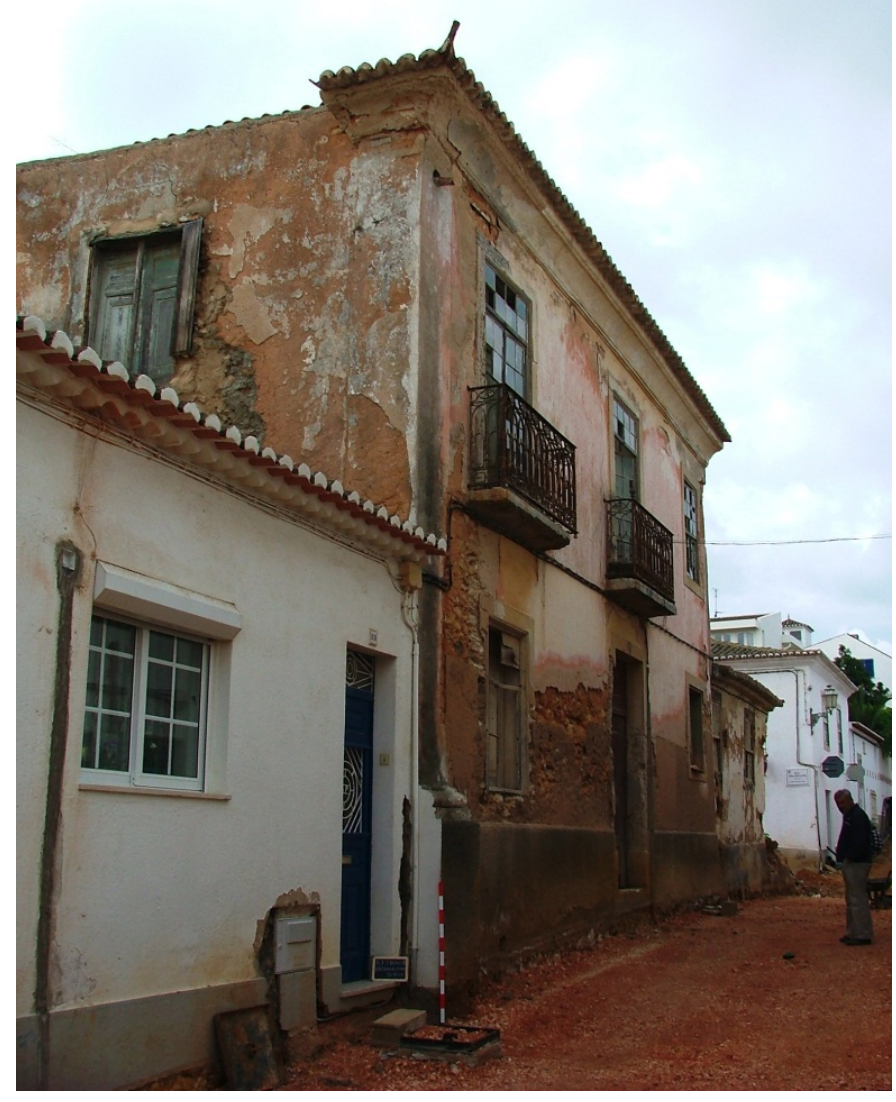

Figura 11. Fachada principal do edifício sito na Rua do Jardim, $n^{\circ} 21$.

\section{Trabalhos realizados}

Em 2005 efectuou-se a primeira campanha de escavação no local graças a um projecto de construção que implicava a demolição total dos edifícios que ali se encontravam, bem como o desaterro de toda a área até uma cota bastante profunda, afectando também possíveis estruturas e outros contextos existentes no subsolo.

Face a este cenário de destruição de todo e qualquer vestígio patrimonial e arqueológico ali existente, iniciouse uma primeira fase de intervenção que tinha por objectivo principal uma leitura geral de todos os elementos estruturais deste complexo de fundação setecentista, composto, em linhas gerais, por uma casa apalaçada de dois andares e respectivo jardim, que se encontrava cercada por uma série de corpos anexos, nomeadamente: três habitações no canto Sudoeste do quarteirão; e quatro no lado Este. Enquanto que as primeiras teriam, em dado momento, comunicação com a habitação principal, as do lado Este terão sido acrescentadas posteriormente, sem qualquer relação com 
a casa senhorial que não a de dependências anexas. Sabemos hoje que estes edifícios seriam alugados a diversas famílias. Pretendia-se para além do registo, compreender o processo construtivo, evolução arquitectónica e técnicas empregues.

Para tal, foi aplicada uma metodologia rigorosa, que permitiu a obtenção de dados suficientes para compor uma sequência cronológica e física da construção de todas as estruturas e caracterizar as técnicas, métodos e materiais construtivos, equilibrando-se as condicionantes próprias de uma intervenção em contexto de obra e as metodologias empregues neste tipo de trabalho. O registo gráfico e fotográfico de todos os espaços da estrutura edificada não foi descurado. Assim, nesta primeira fase de intervenção foram abertas mais de quatro dezenas de sondagens parietais (picagens efectuadas com metodologia arqueológica e registo estratigráfico fotografia, croquis e descrição em ficha específica de cada unidade estratigráfica detectada) e algumas picagens diagnóstico (localizadas próximo das sondagens efectuadas, em locais onde a estratigrafia era já conhecida, e por isso efectuadas sem registo estratigráfico exaustivo), distribuídas por todos os corpos edificados, tanto no interior como no exterior, através das quais se determinaram os métodos construtivos, os tipos de aparelho e de revestimento, as diferenças a nível de paredes interiores e exteriores, bem como momentos construtivos, reconstruções e remodelações (Figuras 12, 13, 14 e 15).

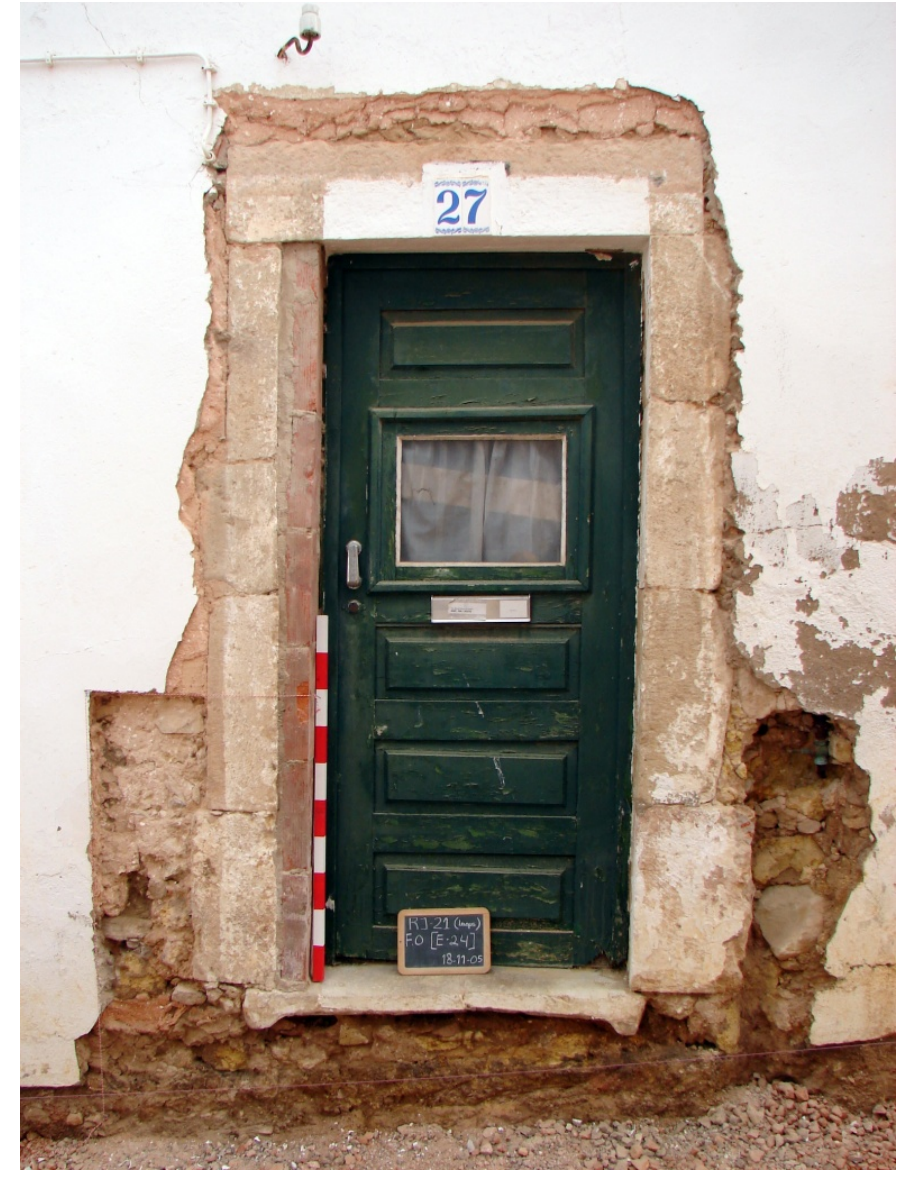

Figura 12. Sondagem efectuada no exterior do edifício.

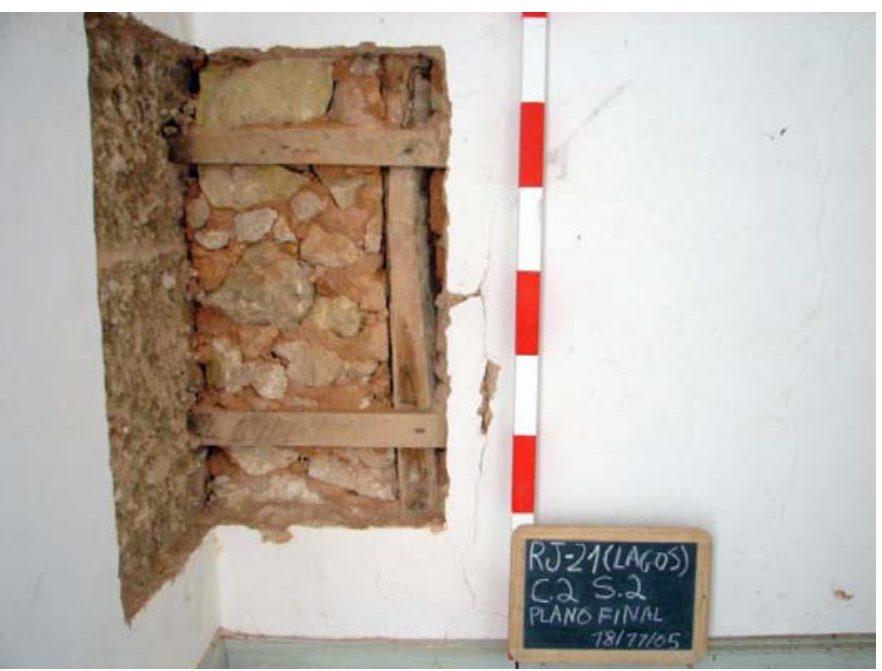

Figura 13. Sondagem efectuada no interior do edifício. 


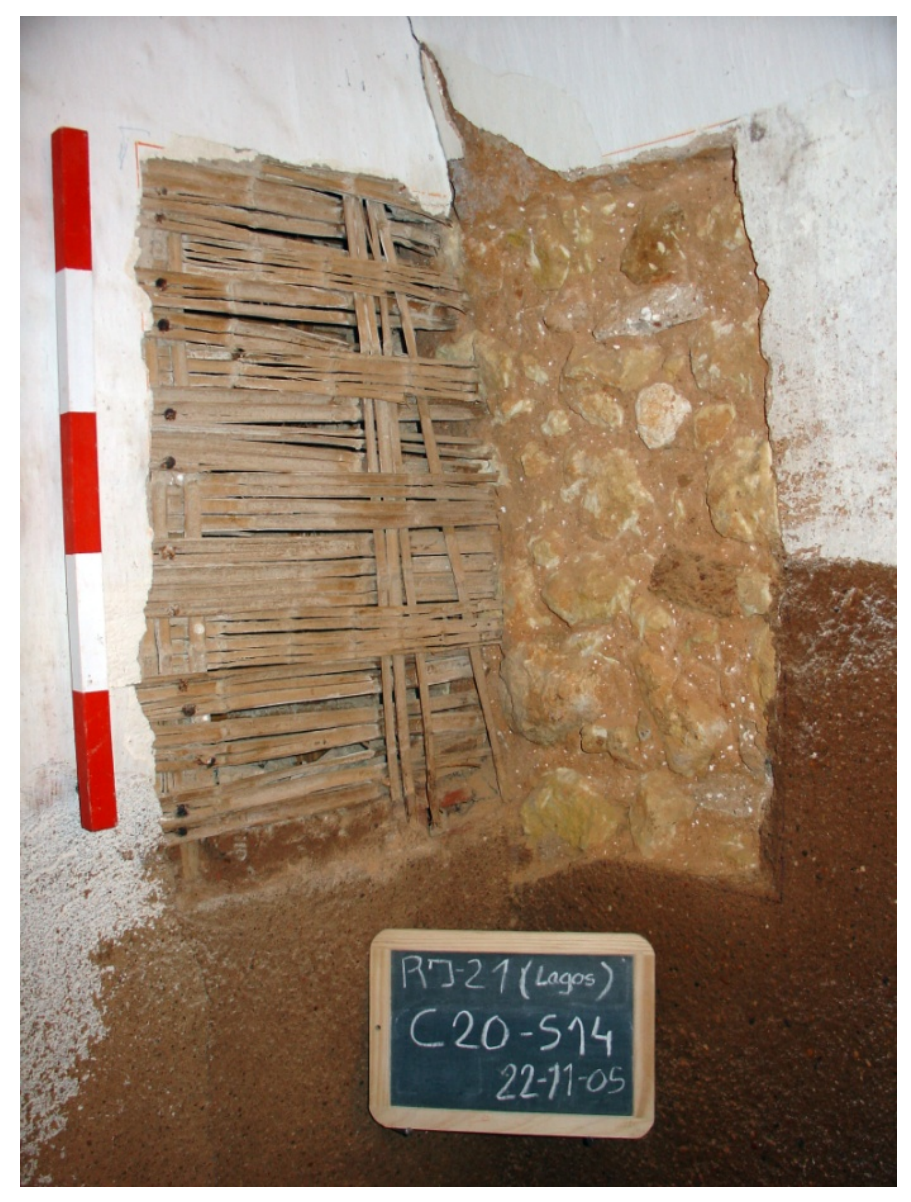

Figura 14. Sondagem efectuada no interior do edifício.

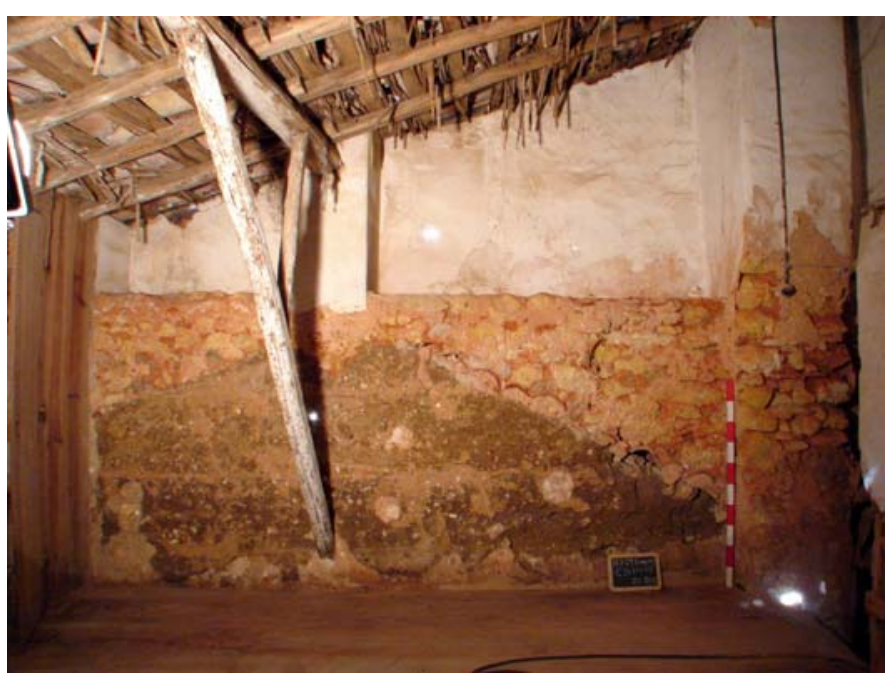

Figura 15. Sondagem efectuada no interior do edifício.
Numa segunda fase, efectuaram-se doze sondagens de diagnóstico no solo, também elas distribuídas pelos diversos edifícios, cuja finalidade foi a de perceber as soluções construtivas no que se refere aos seus alicerces, bem como a possível presença de contextos arqueológicos ou estruturas preexistentes. Pretendia-se assim esclarecer algumas dúvidas levantadas com as sondagens parietais, bem como averiguar a existência de contextos e/ou estruturas anteriores à construção dos edifícios actuais. Após uma paragem de alguns meses, alheia à equipa de arqueologia, retomaram-se os trabalhos entre Junho e Dezembro de 2006, com o acompanhamento por arqueólogo da demolição de grande parte dos edifícios existentes e posterior abertura de sondagens nos locais onde se identificaram contextos e estruturas: na área correspondente ao jardim, onde tinham sido abertas em fase anterior sondagens que revelaram estruturas; e também em novas áreas cuja decapagem revelou a existência de estruturas anteriores à casa senhorial (seis silos, uma interface de possível prensa de azeite e ainda outra, de difícil atribuição, cujas hipóteses apontam para uma estrutura relacionada com a metalurgia ou extraç̧ão de líquidos (SANTOS e FONTES, 2008). Após novo interregno, os trabalhos foram retomados entre Dezembro de 2008 e Janeiro de 2009, acompanhando-se a demolição do que ainda restava da habitação principal, seguida de nova decapagem do terreno com vista à detecção de quaisquer novas estruturas negativas ou positivas (Figura 16). 

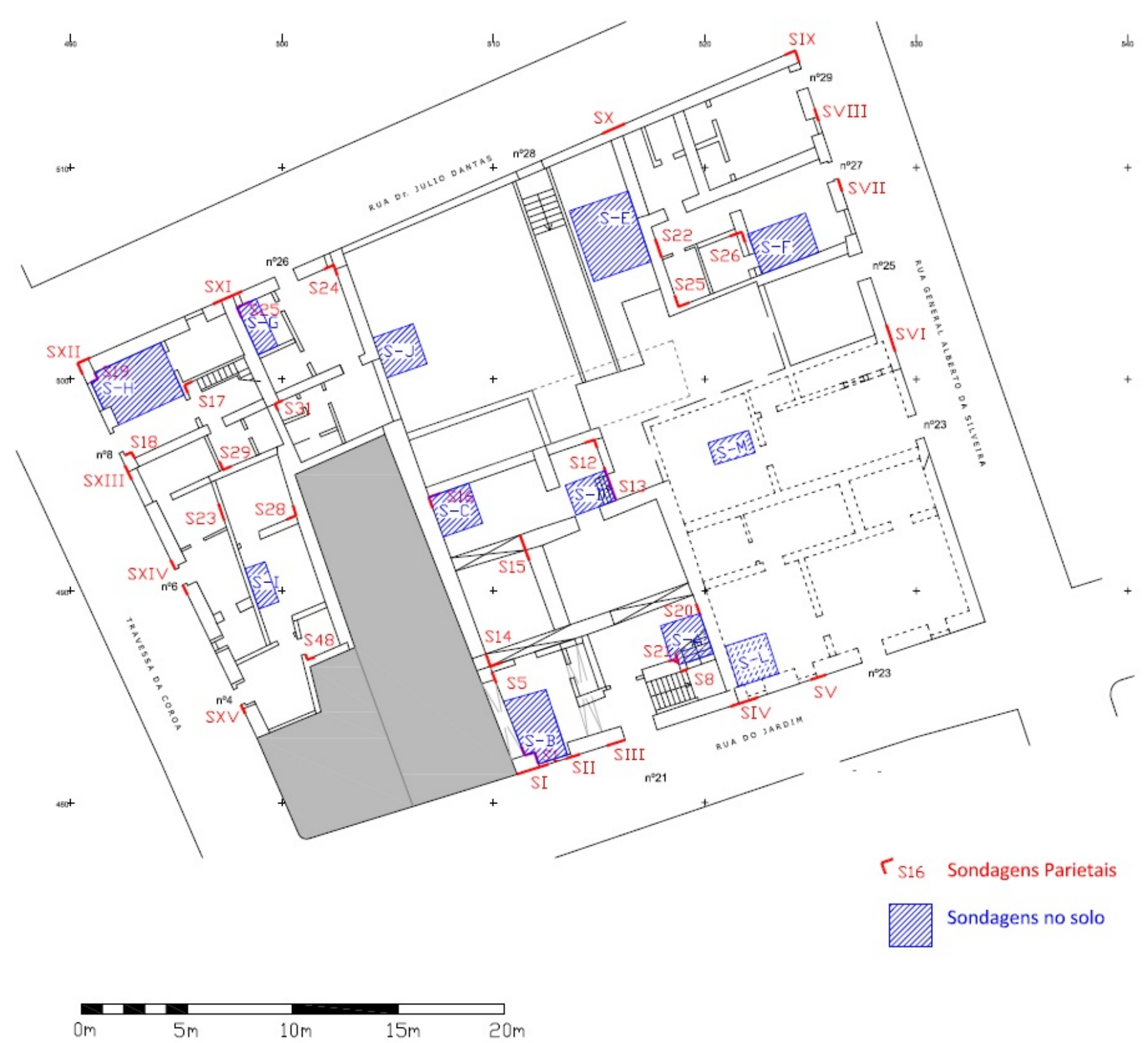

Figura 16. Implantação das sondagens efectuadas ao nível do piso térreo (parietais e no solo).

No que concerne ao desenvolvimento dos trabalhos de campo, estes viram-se condicionados por diversos factores. Em primeiro lugar, pelo facto de um dos edifícios pertencentes ao quarteirão ter sido alvo de demolição antes do início da intervenção arqueológica, cuja área permaneceu interdita até à segunda fase dos trabalhos, devido à acumulação dos entulhos resultantes da demolição. Após a remoção dos entulhos, procedeu-se então à leitura do espaço, embora já bastante fraccionada.

Por outro lado, um outro edifício do quarteirão encontrava-se à data da intervenção habitado e, como tal, excluído do novo projecto de construção, pelo que se manteve sempre à margem do estudo realizado para os restantes edifícios. De qualquer modo, é facilmente perceptível a existência de uma ligação física e funcional entre eles, razão pela qual a exclusão deste espaço da análise efectuada se traduz necessariamente em perda de informação relativamente aos momentos de ocupação na globalidade do quarteirão.

Para além das condicionantes inerentes ao próprio espaço arqueológico, deparámo-nos com outras, de ordem prática, relacionadas sobretudo com a gestão do tempo e recursos, humanos e financeiros, disponíveis para a realização da intervenção. Com um prazo máximo previsto de três meses e uma equipa de apenas seis pessoas, optou-se pela abertura das sondagens parietais 
ao invés de picagens integrais. Muito embora alguns elementos arquitectónicos pudessem escapar aos olhos da equipa, esta opção permitiu cobrir maior área em mais curto espaço de tempo e com menores recursos humanos e obter assim informação, ainda que fragmentada, de todo o conjunto edificado.

A escassez de tempo resultou também na agilização de alguns registos. Nas sondagens no solo e na maioria das sondagens parietais seguiu-se o método de Harris, decapando sucessivamente as camadas estratigráficas e efectuando o seu registo fotográfico e preenchendo uma ficha descritiva para cada uma delas. Contudo, este processo revelou-se moroso e inconciliável com o prazo disponível, tendo em conta o número de sondagens que se pretendia efectuar, pelo que se optou pela simplificação do processo em algumas sondagens parietais, localizadas próximo de outras onde a estratigrafia tinha já sido registada, picando-se todo o conjunto de revestimentos e descrevendo-se a realidade identificada na generalidade e dando-se maior atenção a elementos que não tinham anteriormente sido identificados.

A escolha da metodologia a aplicar foi também condicionada pelas características do complexo edificado: um quarteirão do centro histórico de uma cidade, ocupado por um edifício apalaçado e diversos outros, mais pequenos. Na realidade, a grande maioria das intervenções que utilizam os métodos da Arqueologia da Arquitectura ocorrem em estruturas militares ou religiosas e, como tal, poderão socorrer-se de informação contida em arquivos históricos ou paroquiais como apoio para a investigação. Mas uma intervenção em contexto de arquitectura civil terá sempre um manancial de informação externa inferior. Assim, a pesquisa bibliográfica efectuada antes de iniciados os trabalhos contribuiu para o enquadramento evolutivo do quarteirão em análise e não nos permitiu obter informação histórica específica acerca do edifício em causa, mas apenas para o centro histórico de Lagos no seu contexto geral, pelo que toda a leitura evolutiva do edificado do edifício se socorreu apenas dos dados arqueológicos recolhidos.

Por outro lado, é cada vez mais comum encontrar em determinadas intervenções de reabilitação ou conservação e restauro, metodologias arqueológicas ligadas à arquitectura, que procuram recolher informação acerca do edifício, utilizada posteriormente no próprio projecto de remodelação, muitas vezes até como linha orientadora.

Neste caso, tendo em conta que estava já prevista a total destruição do edifício, a informação recolhida visava sobretudo a conservação da sua memória através de um estudo integral, o qual, idealmente, levaria à plena compreensão do processo construtivo, bem como dos momentos e modelos de ocupação daquele espaço.

Uma nota final para as dificuldades de interpretação registadas. O facto de se terem detectado escassos vestígios de ocupações anteriores à casa senhorial (principalmente se tivermos em conta a dimensão da área intervencionada), na sua maioria muito destruídos e sem contexto fiável ou ligação entre si, foram uma delas. Razão pela qual se estabeleceram apenas duas fases gerais para a ocupação do espaço antes da construção do edifício principal. A análise estrutural foi ainda condicionada pela ocorrência de inúmeras acções de remodelação e reabilitação nos edifícios, decorrentes da necessidade constante de manutenção dos materiais construtivos utilizados (em grande parte a taipa e o tabique, de fraca resistência).

No que respeita à metodologia aplicada, as diversas fases de intervenção na RJ21 contaram com metodologias distintas, embora combinadas entre si.

Para a primeira fase aplicaram-se os métodos da Arqueologia da Arquitectura em numerosas sondagens parietais. De acordo com as condicionantes específicas desta intervenção, foi logo de início posta de parte a possibilidade de picagem integral de qualquer uma das paredes. Ao invés, optou-se pela marcação de sondagens, na sua maioria de $60 \mathrm{~cm} \mathrm{x} 60 \mathrm{~cm}$, distribuídas uniformemente pelos paramentos internos e externos de todos os edifícios que compunham o quarteirão, num total de quinze sondagens no exterior e 31 sondagens no interior. Estas sondagens foram marcadas em locais que permitiam identificar não só o aparelho construtivo, como também o método de construção (adossamentos, remodelações, abertura e estruturação de portas e janelas), numa tentativa de optimizar os recursos existentes. Desta forma, os locais de picagem foram na sua maioria cantos dos compartimentos, esquinas exteriores e zonas adjacentes às portas e janelas.

Todas as sondagens foram descritas pormenorizadamente contando com uma ficha descritiva para cada elemento constituinte, seguindo-se o método de Harris para o registo de todas as unidades estratigráficas, incluindo sobreposições de argamassas, rebocos, etc. Para além dos elementos presentes nas sondagens, foram também identificados e descritos em ficha de unidade estratigráfica própria todos os elementos arquitectónicos presentes nos alçados Norte, Sul, Este e Oeste do quarteirão, compreendendo todos os edifícios neles visíveis, tais como portas, janelas, telhados, beirados, degraus, etc. Em algumas portas foi igualmente feita a picagem manual de toda a cantaria existente.

Tendo por finalidade verificar adossamentos e aparelhos constitutivos, em zonas próximas de sondagens parietais 
já realizadas, no sentido de esclarecer algumas questões relacionadas com a evolução arquitectónica e momentos construtivos dos edifícios, fizeram-se também algumas picagens diagnóstico, de dimensões muito variadas (desde cerca de $20 \mathrm{~cm}$ x $20 \mathrm{~cm}$ ), que não foram alvo de registo minucioso e resultaram da necessidade de obtenção de respostas rápidas nalguns locais específicos dos edifícios a fim de completar a sequência construtiva dos mesmos.

Procedeu-se ainda ao registo fotográfico de todas as realidades identificadas nas sondagens parietais, assim como ao levantamento fotográfico de todas as fachadas e de todos os compartimentos, registando-se não só a generalidade dos espaços, mas também tectos, soalhos, pavimentos, elementos decorativos, gama cromática das paredes internas, portas, janelas, etc. Fez-se igualmente o registo gráfico de todas as estruturas em planta, identificando-se os tipos de aparelho utilizado e sequência cronológica de construção (Figura 17).

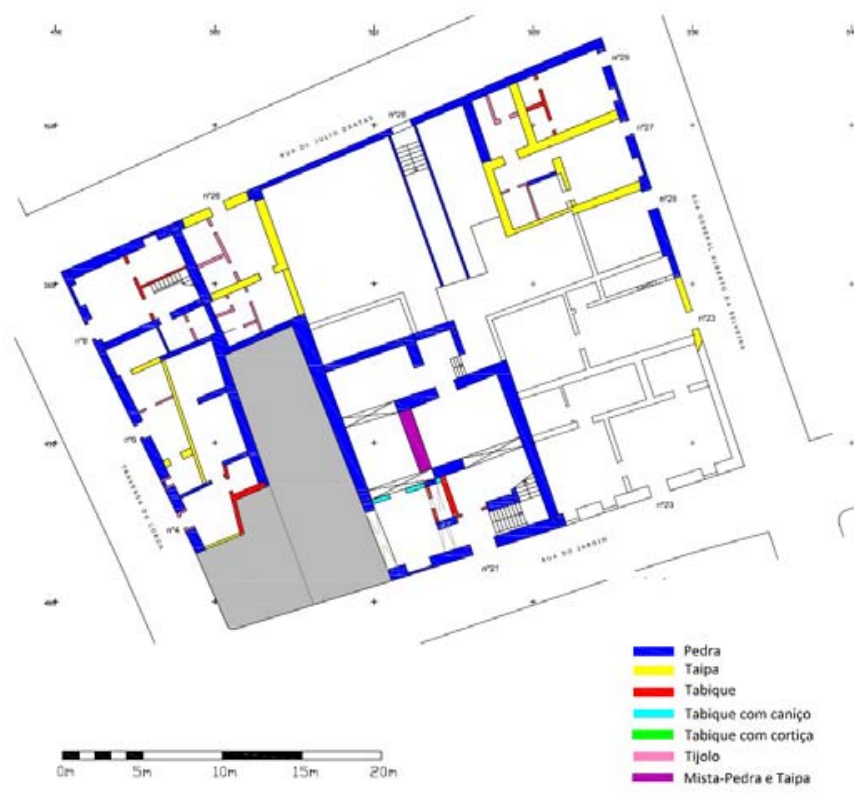

Figura 17. Análise estrutural efectuada ao nível do piso térreo.

A segunda fase de intervenção contou com a abertura de doze sondagens no solo (nove no interior dos edifícios e três no exterior), de dimensões diversas, implantadas segundo critérios em parte definidos pelas sondagens parietais, procurando-se conhecer e registar eventuais preexistências e analisar as estratégias construtivas adoptadas para os alicerces do conjunto edificado.

A escavação arqueológica da área de sondagem, até ao nível geológico de margas, foi feita manualmente, por decapagem de camadas arqueológicas, seguindo o método de Harris e registando-se todas as unidades estratigráficas (UE's), preservando sempre um ou mais cortes estratigráficos para registo gráfico e fotográfico.
O registo gráfico da escavação consistiu em desenho de planos, cortes e alçados de cada uma das sondagens à escala 1:20, com indicação das unidades estratigráficas. Registaram-se fotograficamente os planos e cortes estratigráficos de todas as unidades detectadas. Para além deste tipo de registos, foi feita a descrição de cada realidade estratigráfica em fichas específicas e no Caderno de Campo.

O material arqueológico recolhido no decurso destas sondagens no solo recebeu um tratamento preliminar, nomeadamente lavagem, marcação e inventariação sumária.

Na terceira fase da intervenção arqueológica (FONTES, 2007) efectuou-se o acompanhamento por arqueólogo da demolição da maior parte dos edifícios, mantendo-se apenas as divisões da casa senhorial que se encontravam junto da sua fachada principal. No decurso da remoção do entulho resultante, recuperaram-se diversas pedras de cantaria que haviam sido reaproveitadas nas portas ou mesmo nas paredes. Destacam-se as pedras de ombreira e de lintel chanfradas, cronologicamente enquadráveis nos séculos XVI e XVII e as pedras de soleira com orifício de tranca (SANTOS e FONTES, 2008). Removido o entulho, efectuou-se a decapagem mecânica de toda a área, até ao nível do substrato, registando-se fotograficamente 0 decurso dos trabalhos. Esta decapagem do terreno permitiu a identificação de estruturas e contextos, de cronologia anterior aos edifícios demolidos, os quais foram posteriormente escavados seguindo a metodologia empregue para as sondagens no solo.

\section{Síntese interpretativa}

O conjunto das sondagens (parietais e no solo) realizadas nas diferentes fases de intervenção forneceu uma cabal evolução construtiva e cronológica do conjunto edificado, assim como do próprio espaço em que este se insere, permitindo determinar os métodos construtivos, os tipos de aparelho e de revestimento, as diferenças a nível de paredes interiores e exteriores, mas também os diversos momentos de ocupação daquela área do centro histórico de Lagos. A metodologia empregue possibilitou não só o diagnóstico da realidade arqueológica existente, mas também superar alguns problemas, advindos sobretudo da localização no centro histórico da cidade, da utilização de materiais construtivos com alto índice de manutenção, da influência do terramoto de 1755 em toda a zona, bem como da própria dimensão e complexidade do espaço arqueológico (SANTOS, et alii, 2006).

No decurso das sondagens no solo foi recolhido um vasto espólio, constituído por milhares de fragmentos cerâmicos, vítreos, metálicos, osteológicos, 
malacológicos e ictiológicos, que permitiu datar com maior segurança algumas dessas fases de ocupação. O espólio recolhido no decurso da segunda e terceira fase de intervenção possibilitou não só a caracterização dos hábitos alimentares e outros aspectos quotidianos da população que ali residiu ao longo de, pelo menos, cinco séculos, mas também uma cronologia mais apurada para a construção e abandono de algumas das estruturas. Na realidade, nos diferentes espaços intervencionados surgiram conjuntos artefactuais enquadráveis entre os séculos XIV e XVIII. Foi recolhida uma grande variedade de tipologias de cerâmica comum, cerâmica de vidrado plumbífero e cerâmica de vidrado estanífero, bem como outro tipo de objectos cerâmicos, como por exemplo cachimbos em caulino. Recuperaram-se também alguns fragmentos de peças em vidro e metal, restos osteológicos de cabra ou ovelha, galinha, cavalo, coelho, vaca e porco; restos malacológicos de berbigão, ostra, lapa, mexilhão, vieira, amêijoa, navalheira, búzio e burriés; e ainda restos ictiológicos de diversas espécies, muito embora se tenha identificado apenas o atum (SANTOS, et alii, 2005). Alguns materiais osteológicos provenientes de diferentes silos permitiram obter três datações de C14 entre os anos 1300-1450 (dois casos) e $1410-1520^{2}$ (Figura 18).

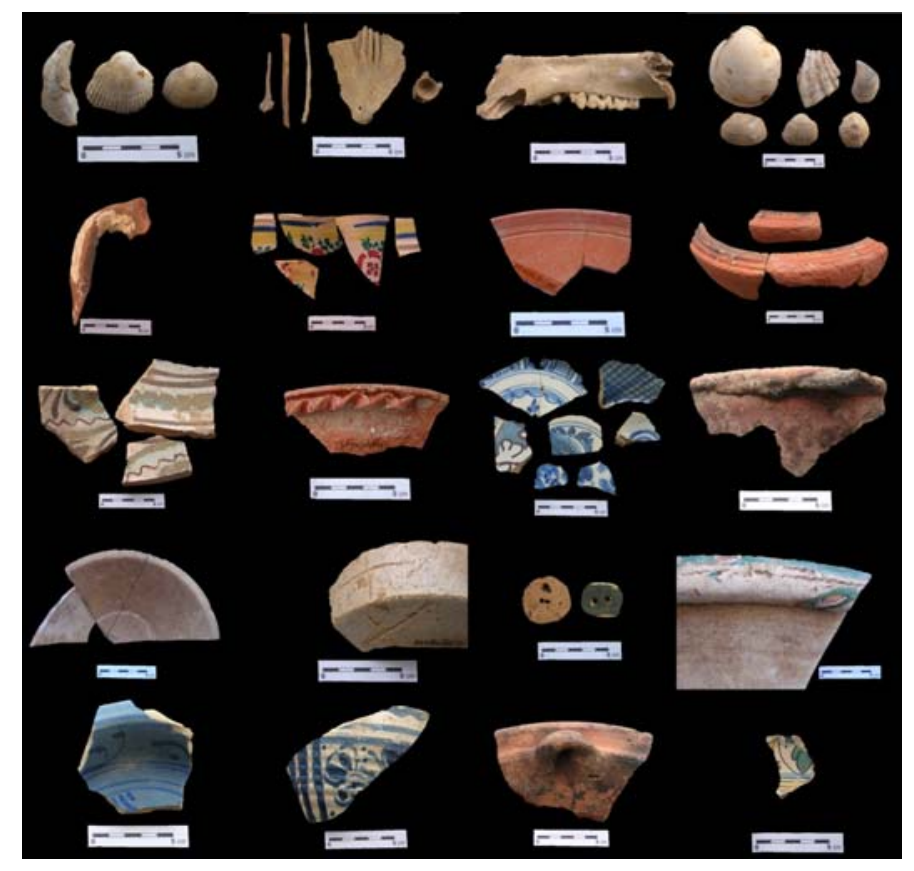

Figura 18. Alguns dos materiais arqueológicos recolhidos no decurso das sondagens no solo, que permitiram uma atribuição cronológica aos momentos de ocupação e abandono daquele espaço.

A análise estrutural, levada a cabo através do cruzamento dos dados das sondagens com a observação das plantas e alçados dos edifícios, resultou na identificação de diferentes aparelhos construtivos, revestimentos e acabamentos das paredes, pisos, tectos, beirados e telhados, levando em alguns casos a uma atribuição funcional a cada um dos tipos. Mais especificamente, foram detectados quatro tipos de aparelho construtivo diferentes: a alvenaria ordinária (de pedra calcária irregular), a alvenaria em tijolo (tijolo burro e tijolo furado), a taipa (com blocos de dimensões variáveis) e o tabique (com enchimento de pedra calcária ou cortiça, com estrutura em madeira ou ripado de canas entrelaçadas). O reboco de argamassa de cal e areia, de argamassa de cimento, o estuque e o azulejo foram os revestimentos identificados (Figura 19).

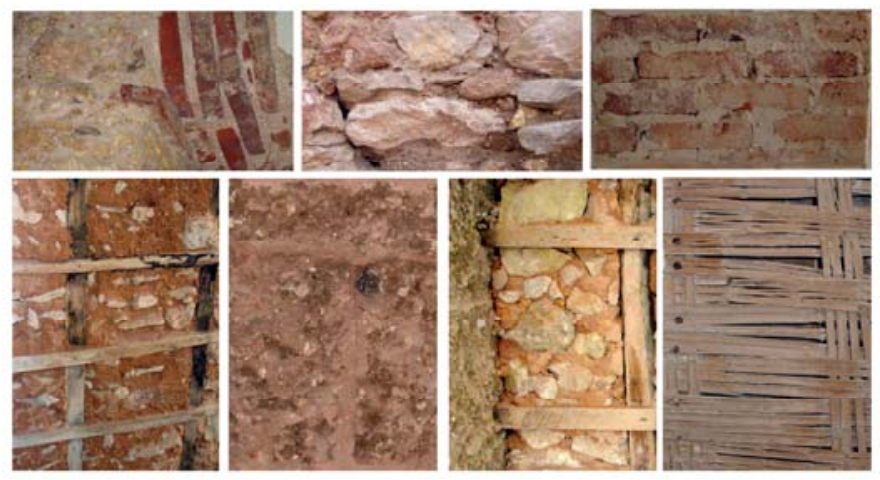

Figura 19. Exemplos de diferentes aparelhos detectados.

No que diz respeito aos pisos, os mais recentes contavam com mosaico ou argamassa de cimento e os mais antigos com ladrilho cerâmico, soalho de madeira ou terra batida, existindo ainda um pequeno troço de calçada de seixos com motivo geométrico. Quanto aos tectos, registaram-se abóbadas - estruturadas numa armação de cana entrelaçada coberta por gesso - e tectos falsos em madeira ou contraplacado, ou seguindo o mesmo método construtivo das abóbadas. Ao nível dos acabamentos registaram-se diversos tipos de pintura e elementos decorativos, destacando-se os fingidos em gesso (colunas, capitéis, arcos) e sancas trabalhadas (em madeira e gesso), exclusivamente existentes no edifício principal. Já no exterior, registaram-se telhados constituídos por telha de canudo com travamento de valadio ou mouriscado ${ }^{3}$ e telha em aba e canudo com travamento por encaixe, ambos com telhão nos limites das águas; e beirados em cornija ou sub-beira dupla (SANTOS, et alii, 2007). Pela observação dos diferentes tipos de aparelho construtivo registou-se a utilização da alvenaria ordinária nas paredes-mestras do rés-do-chão dos diversos edifícios, reservando-se o tabique e o tijolo (nas remodelações mais recentes) para as paredes divisórias internas. A taipa, aparelho mais comum, foi utilizada na paredes-mestras do primeiro andar bem como nas paredes dos edifícios térreos.

Foi possível também estabelecer uma análise evolutiva de todo o espaço, com base nos dados das diferentes fases de intervenção. Assim, criou-se uma sequência de construção que conta com cinco fases distintas, desde a 3construção dos elementos mais antigos detectados sob 
as estruturas à edificação do novo empreendimento, passando pelo apogeu da casa senhorial e abandono de todo o espaço.

A Fase 1 corresponde à utilização do espaço anterior à construção da casa senhorial, nomeadamente dos silos e interfaces de estruturas de apoio a actividades de preparação de azeite, forja ou outras, cujo abandono se baliza nos séculos XV/XVI.

A Fase 2 reporta-se à construção, a partir de finais do século XVII, das estruturas detectadas em escavação sob a casa senhorial e, provavelmente, arrasadas pelo terramoto.

A Fase 3 da sequência evolutiva estabelecida para aquele quarteirão é a mais longa e surge após o terramoto de 1755, altura em que se constrói a casa senhorial e, posteriormente, os edifícios envolventes, uniformizando o espaço até ao século XIX.

Já a Fase 4 corresponde grosso modo ao tempo presente, com o abandono da casa senhorial e sua posterior recuperação, no século $\mathrm{XX}$, com todas as alterações inerentes, nomeadamente a independência dos edifícios circundantes.

A Fase 5 tem lugar entre o presente e o tempo futuro, com a construção do novo empreendimento imobiliário que virá uniformizar novamente todo o espaço (SANTOS e FONTES, 2008).

Os dados das sondagens parietais permitiram elaborar também uma sequência evolutiva com vários momentos, dentro da Fase 3, correspondente à construção da casa senhorial e edifícios anexos (Figuras 20, 21 e 22).

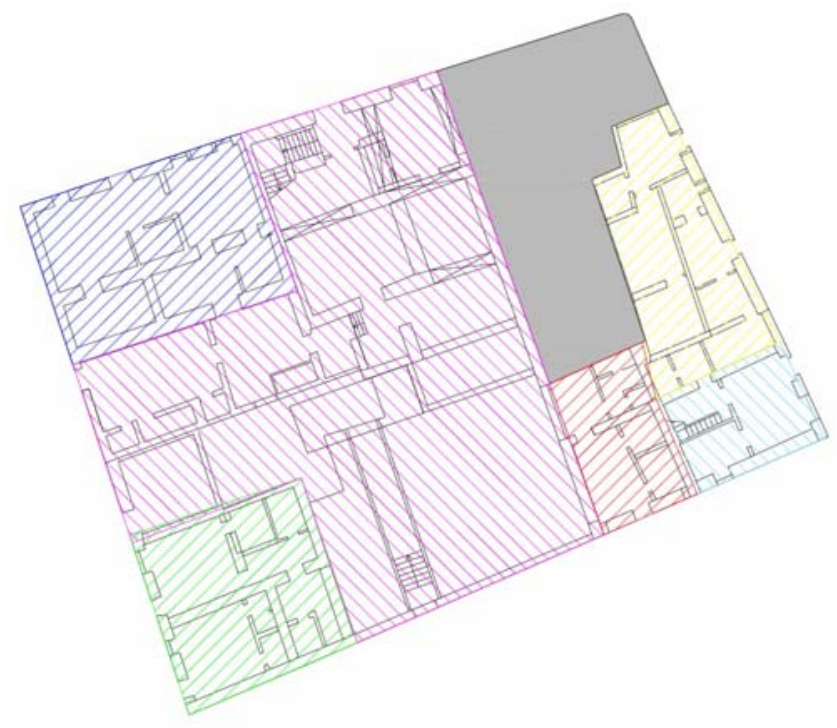

Figura 20. Momento 1: construção da casa senhorial (magenta); Momento 2: reconstrução do edifício a Nordeste após derrocada (azul); Momento 3: construção dos dois edifícios anexos a Oeste (verde); Momento 4: construção dos três edifícios anexos a Este (vermelho, azul claro e amarelo).

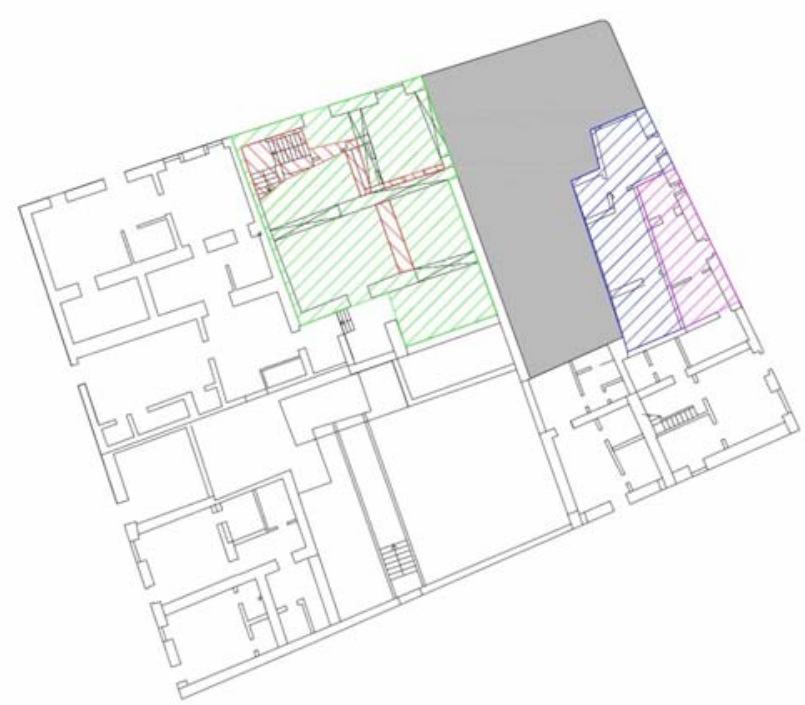

Figura 21. Momento 5: Subdivisão do edifício anexo a Este (azul e magenta) e alterações efectuadas ao espaço de armazém no piso térreo da casa senhorial (vermelho e verde).

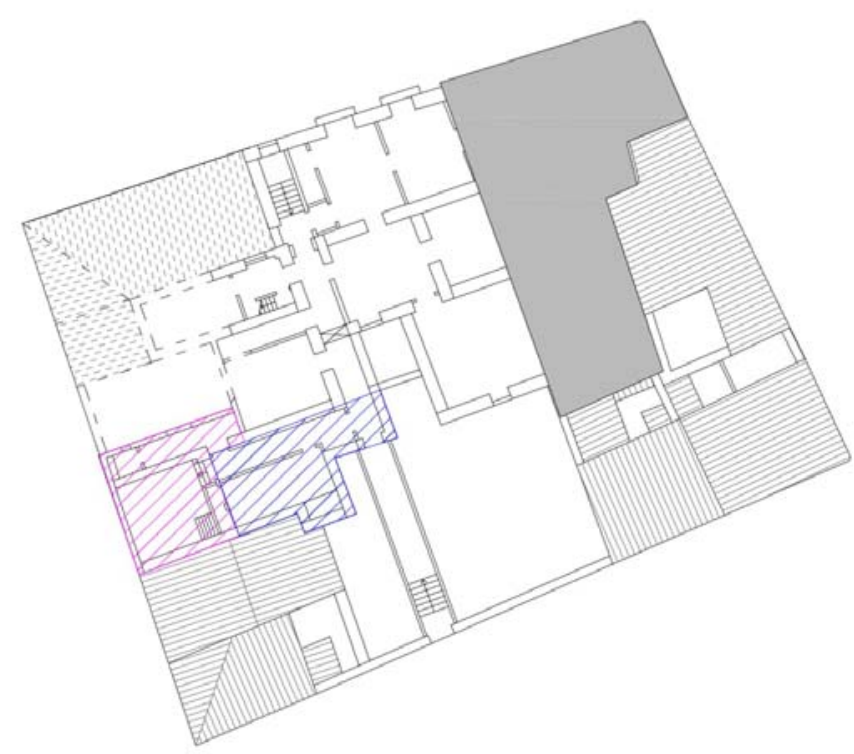

Figura 22. Momento 5: Acrescento na casa senhorial, na área da cozinha e sótão (azul e magenta).

$\mathrm{Na}$ realidade, face à eminente destruição de todo o conjunto, recolheram-se dados suficientes para a construção de uma sequência mais pormenorizada da construção e evolução do complexo edificado (Fase 3), com todas as transformações e remodelações que foi possível registar, distribuídas por cinco momentos. A elaboração desta sequência pormenorizada permitiu, apenas a título de exemplo, (1) apurar o facto de a fachada principal da casa senhorial ter sido construída em dois momentos, uma vez que, a dada altura, terá havido uma derrocada, reconstruindo-se posteriormente embora em moldes distintos dos originais; (2) situar o momento 
de utilização de algumas portas e janelas emparedadas à data da intervenção e já sem função evidente (alteração dos espaços com os quais fariam a comunicação); (3) compreender as remodelações e alterações na função dos espaços da casa senhorial; ou ainda (4) perceber que os edifícios anexos, originalmente parte integrante da casa principal, foram sendo sucessivamente subdivididos em habitações mais pequenas.

Assim, pela compilação dos dados estabeleceram-se cinco momentos principais para a construção e utilização dos edifícios existentes na Fase 3: (1) a construção (ou reconstrução) da casa senhorial no pósterramoto; (2) a reconstrução do edifício no canto Noroeste do quarteirão, após a queda/demolição de parte da fachada Oeste; (3) a construção das habitações situadas no lado Sul e Oeste; (4) a construção das habitações no limite Este e (5) as alterações realizadas nos vários núcleos habitados após a definição das fachadas em todos os limites do quarteirão.

Foi também possível perceber que até muito tarde, inclusive durante o século XIX e XX, foram feitas alterações no interior das casas, seccionando espaços anteriormente amplos, reduzindo espaços abertos de pátio para construção de estruturas de cozinha e casa de banho, reconstruindo paredes já existentes, e aplicando novos tipos de piso, entre outros, o que atesta a impossibilidade de uma interpretação linear da evolução do espaço (SANTOS, et alii, 2005), remetendo-se estas pequenas alterações para o referido momento 5 .

Tendo em conta a devastação ocorrida na cidade de Lagos aquando do terramoto de 1755 e a fraca resistência dos materiais utilizados, acreditamos que as estruturas mais antigas actualmente existentes no quarteirão tenham sido edificadas no pós-terramoto. Provavelmente, terá sido seguida a traça anterior, uma vez que se nota na casa principal uma planta típica do séc. XVII, com a existência de armazéns no rés-do-chão, uma zona nobre e uma zona de serviço no $1^{\circ}$ andar, e uma torre de três pisos ao centro da casa. Existe ainda, nas traseiras, o jardim, a cisterna e um saguão. Por outro lado, nota-se também o reaproveitamento de cantarias aparelhadas e chanfradas (típicas do século XVI) em algumas portas, possivelmente provenientes de edifícios preexistentes

Assim, em traços gerais, o espaço arqueológico teria sido inicialmente ocupado por algumas estruturas relacionadas com actividades artesanais, após o abandono das quais se construiu o primeiro grande edifício daquele local. Este terá sido arrasado com o terramoto de 1755, reconstruindo-se posteriormente, dentro dos mesmos moldes.

A nova habitação, de grandes dimensões e planta característica do século XVII, contava com uma zona nobre, uma zona de serviço, os armazéns, a cisterna e o jardim. A este edifício foram adossadas outras dependências, mais tarde independentes e ocupadas por diversas famílias. Todo o conjunto terá sido alvo de constante manutenção, devido à precariedade do aparelho construtivo, e de sucessivas remodelações, mercê da alteração da função dos diversos espaços.

Em suma, através de uma colaboração eficaz entre as partes envolvidas, foi possível realizar um estudo intensivo de uma parte importante da zona histórica de Lagos. Recuperou-se uma percentagem elevada dos dados arqueológicos que a área intervencionada podia oferecer, muito embora os resultados obtidos ao longo desta intervenção devam ainda ser consolidados através do estudo mais aprofundado do abundante material arqueológico recolhido. Os resultados apresentados (SANTOS, et alii, 2005; SANTOS e FONTES, 2008; SANTOS, et alii, 2007) deverão também ser comparados com as conclusões obtidas em outras intervenções similares realizadas na cidade de Lagos, contribuindo assim para uma melhor compreensão da evolução daquele núcleo urbano.

\section{Conclusões}

Os exemplos apresentados, de características diferentes entre si e alvo de intervenções arqueológicas com objectivos também diferentes, embora partindo de uma mesma base metodológica, proporcionam diferentes conhecimentos acerca dos edifícios a que se referem e sobre diferentes aspectos da vida quotidiana das populações que com eles se relacionam.

Embora variando o objecto de estudo (desde o edifício de habitação em meio rural ou no centro histórico de uma grande cidade ao edifício militar junto à costa ou religioso no isolamento da montanha) e o contexto da intervenção (obras de conservação e restauro, projecto de investigação, demolição total, etc.), a Arqueologia da Arquitectura é sempre adaptável às condicionantes específicas que sujeitam cada trabalho, sejam elas de ordem física (tipologia do edificado), financeira (verbas e prazos envolvidos) ou outra.

A sua aplicação no estudo de um edifício histórico ou conjunto edificado permite, em qualquer dos casos, recolher dados científicos para a criação de um modelo interpretativo do objecto de estudo, visando como fim último o conhecimento do Homem e da Cultura que o gerou.

Estes exemplos levantam apenas a ponta do véu da Arqueologia da Arquitectura, sob o qual se encontram tantas outras intervenções através das quais realizamos a verdadeira importância da análise parietal com metodologia arqueológica, uma prática que, apesar dos 
esforços, não se encontra ainda totalmente generalizada e aceite pelos profissionais que operam em património construído.

\section{Notas}

(1) Picagem - remoção manual dos rebocos e demais revestimentos da parede com recurso a ferramentas como escopro e martelo.

(2) Datações efectuadas no Instituto Tecnológico e Nuclear pelo Eng. António Monge Soares, divulgadas no $7^{\circ}$ Encontro de Arqueologia do Algarve que teve lugar em Silves, em Outubro de 2009, na comunicação intitulada "A cultura material e diacronia dos silos da Rua do Jardim n 21 (Lagos)”, da autoria de Tiago Fontes e Severino Rodrigues.

(3) O travamento de valadio é feito com juntas abertas, sem argamassa, permitindo a entrada de ar no espaço entre a cobertura da edificação e os forros. Já o travamento mouriscado utiliza telhas cujas juntas são cobertas com fragmentos de telha e argamassa (ALBERNAZ e LIMA, 1998, p.604).

\section{Referências}

ALBERNAZ, Maria Paula, LIMA, Cecília Modesto, Dicionário Ilustrado de Arquitectura, Rio de Janeiro, Pro Editores, $2^{\circ}$ Vol., $1^{\text {a }}$ Edição, 1998.

CABALLERO ZOREDA, L. (1997), "Arqueología y arquitectura: Análisis arqueológico e intervención en edificios históricos", in Curso As Actuacións no patrimonio construído: un diálogo interdisciplinar (1995, Santiago de Compostela), s.l.: Xunta de Galicia, p. 131-158 e 457-469.

CABRITA, A. R., AGUIAR, J. e APPLETON, J. (1992), Manual de Apoio à Reabilitação dos Edifícios do Bairro Alto, Lisboa: Câmara Municipal de Lisboa e Laboratório Nacional de Engenharia Civil, 203 pp.

FONTES, T. Intervenção Arqueológica na Rua do Jardim, no 21, Lagos. $3^{\mathrm{a}}$ Fase. Lisboa. Relatório entregue ao Instituto Português de Arqueologia, Fevereiro 2007.

RAMALHO, M. M. B. D. M. (1996), "A arqueologia na intervenção dos edifícios históricos ou a Arquelogia da Arquitectura", in Al-Madam, II série, n 5, Almada: Centro de Arqueologia de Almada, pp. 50-56.

RAMOS, L. F. e LOURENÇO, P. B., “Análise das técnicas de construção pombalina e apreciação do estado de conservação estrutural do quarteirão do Martinho da Arcada”, in. Engenharia Civil, no 7, s.l.: Universidade do Minho e Departamento de Engenharia Civil, pp. 35-46.

SANTOS, R.; FONTES, T. Intervenção arqueológica na Rua do Jardim, nº 21. Centro Histórico de Lagos, Xelb 8 . Actas do $5^{\circ}$ Encontro de Arqueologia do Algarve (Silves, 25 a 27 de Outubro 2007). Silves: Câmara Municipal de Silves, p. 341-363, 2008.

SANTOS, R.; FONTES, T.; REBELO, P.; NETO. N. Intervenção arqueológica na Rua do Jardim, n. ${ }^{\circ}$ 21, Lagos (1ª fase). Lisboa. Relatório entregue ao Instituto Português de Arqueologia, Dezembro 2005.

SANTOS, R.; FONTES, T.; REBELO, P.; NETO. N. Intervenção arqueológica na Rua do Jardim, n. ${ }^{\circ}$ 21, Lagos (2ª fase). Lisboa. Relatório entregue ao Instituto Português de Arqueologia, Fevereiro 2006.

SANTOS, R.; FONTES, T.; REBELO, P.; NETO. N. Intervenção Arqueológica na Rua do Jardim, Lagos. Pedra \& Cal. Revista da Conservação do Património Arquitectónico e da Reabilitação do Edificado, Lisboa: GECoRPA - Grémio das Empresas de Conservação e Restauro do Património Arquitectónico, Ano IX - nº 35, p. 28-29, 2007.

SANTOS, R. Relatório da Intervenção Arqueológica na Rua dos Bacalhoeiros, $\mathrm{n}^{\circ}$ 28, Lisboa. Sondagens Parietais. Lisboa. Relatório entregue ao Instituto de Gestão do Património Arquitectónico e Arqueológico, Agosto 2007.

SANTOS, R. Relatório Final da Intervenção Arqueológica na Rua dos Bacalhoeiros, n 28, Lisboa. Lisboa. Relatório entregue ao Instituto de Gestão do Património Arquitectónico e Arqueológico, Agosto 2011.

SILVA, A. C. (1986), "A Cidade e a Arqueologia", in Trabalhos de Arqueologia. I Encontro Nacional de Arqueologia Urbana. Setúbal, 24 a 26 de Maio de 1985, 03, Lisboa: Ministério da Educação e Cultura, Secretaria de Estado da Cultura, IPPC e Departamento de Arqueologia/Serviços Nacionais de Arqueologia, pp. 7-11.

\footnotetext{
${ }^{\mathrm{I}}$ Raquel Santos

Arqueóloga, licenciada em História, com ênfase em Arqueologia pela Faculdade de Ciências Sociais e Humanas da Universidade Nova de Lisboa e mestre pela Universidade do Algarve, na área de Teoria e Métodos da Arqueologia.
}

\footnotetext{
II Paulo Rebelo

Arqueólogo, licenciado em História, com ênfase em Arqueologia pela Faculdade de Ciências Sociais e Humanas da Universidade Nova de Lisboa (UNL) e mestre pela Universidade de Algarve na área de Teoria e Métodos da Arqueologia.
}

\footnotetext{
III Nuno Neto

Arqueólogo, licenciado em História, com ênfase em Arqueologia pela Faculdade de Ciências Sociais e Humanas da Universidade Nova de Lisboa e mestre pela mesma faculdade. Especialista em Geoarqueologia na Faculdade de Ciências de Lisboa.
} 